Research Article

Genetic of Microorganisms

\title{
Genomic analysis of Enterococcus durans LAB18S, a potential probiotic strain isolated from cheese
}

\author{
Carolina Baldisserotto Comerlato ${ }^{1}$ (D), Janira Prichula ${ }^{2}$, Franciele Maboni Siqueira ${ }^{3}$, Ana Carolina Ritter ${ }^{1}$ \\ Ana Paula Muterle Varela ${ }^{4}$, Fabiana Quoos Mayer ${ }^{4}$ and Adriano Brandelli ${ }^{1}$ (D) \\ ${ }^{1}$ Universidade Federal do Rio Grande do Sul, Departamento de Ciencia de Alimentos, Laboratório \\ de Bioquímica e Microbiologia Aplicada, Porto Alegre, RS, Brazil. \\ ${ }^{2}$ Universidade Federal de Ciências da Saúde de Porto Alegre, Laboratório de cocos Gram-positivos, \\ Porto Alegre, RS, Brazil. \\ ${ }^{3}$ Universidade Federal do Rio Grande do Sul, Departamento de Patologia Clínica Veterinária, \\ Laboratório de Bacteriologia Clínica, Porto Alegre, RS, Brazil. \\ ${ }^{4}$ Secretaria da Agricultura Pecuária e Irrigação do RS, Departamento de Diagnóstico e Pesquisa \\ Agropecuária, Laboratório de Biologia Molecular, Eldorado do Sul, RS, Brazil.
}

\begin{abstract}
Gut microbiota exerts a fundamental role in human health and increased evidence supports the beneficial role of probiotic microorganisms in the maintenance of intestinal health. Enterococcus durans LAB18S was previously isolated from soft cheese and showed some desirable in vitro probiotic properties, for that reason its genome was sequenced and evaluated for genes that can be relevant for probiotic activity and are involved in selenium metabolism. Genome sequencing was performed using the Illumina MiSeq System. A variety of genes potentially associated with probiotic properties, including adhesion capability, viability at low $\mathrm{pH}$, bile salt resistance, antimicrobial activity, and utilization of prebiotic fructooligosaccharides (FOS) were identified. The strain showed tolerance to acid $\mathrm{pH}$ and bile salts, exhibited antimicrobial activity and thrived on prebiotic oligosaccharides. Six genes involved in selenium metabolism were predicted. Analysis of the SECIS element showed twelve known selenoprotein candidates. E. durans LAB18S was the only food isolate showing absence of plasmids, virulence and antimicrobial resistance genes, when compared with other $30 \mathrm{E}$. durans genomes. The results of this study provide evidence supporting the potential of $E$. durans LAB18S as alternative for probiotic formulations.
\end{abstract}

Keywords: Enterococcus, probiotc, prebiotic, genome, selenoproteins.

Received: July 14, 2021; Accepted: January 03, 2022.

\section{Introduction}

Enterococcus genus belongs to the group of lactic acid bacteria (LAB) of the phylum Firmicutes, showing the ability to survive under various environmental conditions (Byappanahalli et al., 2012). This genus is an important component of the intestinal microbiota of humans and other animals and is found in commercial products, such as Cernivet ${ }^{\circledR}$ and FortiFlora ${ }^{\circledR}$ (containing Enterococcus faecium SF68 ${ }^{\circledR}$, Cerbios -Pharma SA, Switzerland) and Symbioflor ${ }^{\circledR} 1$ with Enterococcus faecalis (Symbiopharm, Herborn, Germany) (Hanchi et al., 2018). Many enterococci isolated from fermented dairy products proven to be natural probiotics and have been considered beneficial and safe to the host (Franz et al., 2011).

Currently, the role of probiotic bacteria in gut health and functionality of human, livestock animals and pets has been greatly emphasized. The intestinal microbiome has a great importance in human health, promoting intestinal homeostasis,

Send correspondence to Adriano Brandelli. Universidade Federal do Rio Grande do Sul, Departamento de Ciência de Alimentos, Laboratório de Bioquímica e Microbiologia Aplicada, Av. Bento Gonçalves 9500, 91501-970, Porto Alegre, RS, Brazil.

E-mail: abrand@ufrgs.br. development of the immune system, protection against pathogens and stimulating the production of micronutrients and energy (Clemente et al., 2012; Martín and Langella, 2019).

Some in vitro assays are recommended to characterize a microorganism with probiotic potential, including adherence to human and/or mucosal epithelial cells, antimicrobial activity against pathogens, ability to decrease the adhesion of pathogens and stimulate the hydrolysis of bile salts (Hill et al., 2014). These assays have become the dogma for probiotic characterization, but phenotypic characterization is not enough to provide a full description of probiotic microorganisms. Thus, the study of genomic data obtained by high-throughput DNA sequencing tools may provide novel useful information, expanding the current knowledge on probiotic strains. Genomic analysis may be useful to identify genes related to probiotic properties and to find additional molecules and metabolic routes that contribute to the specific activity of a probiotic strain (Li et al., 2018). These genes can codify proteins associated with survival to gastrointestinal tract transit, such as bile salt hydrolases, production of antimicrobial substances like bacteriocins, and beneficial enzymes, such as $\beta$-galactosidase (BGL) and inulinase (Ladero et al., 2013; Bonacina et al., 2017).

In addition to these probiotic characteristics, antioxidant properties play an important role and can be associated to the 
ability of a probiotic to produce selenoproteins. Selenium (Se) is a trace element known primarily for its functions in redox homeostasis as a promising chemo-preventive agent for cancer (Hartfield et al., 2006) and because it has beneficial effects associated with probiotic bacteria (Galano et al., 2013). The major biological form of $\mathrm{Se}$ is selenocysteine (Sec, the $21^{\text {st }}$ amino acid), which is co-translationally inserted into selenoproteins by recoding the UGA codon (Hatfield and Gladyshev, 2002). In bacteria, the mechanism of Sec biosynthesis and its insertion into proteins requires an inframe UGA codon, a Sec insertion sequence element (SECIS). SECIS is a hairpin structure within the selenoprotein mRNA immediately downstream of the Sec codon encoding the UGA codon (Zhang and Gladyshev, 2005).

Although genome sequences of Enterococcus species like E. faecalis and E. faecium have been largely described (Bonacina et al., 2017; Zhong et al., 2017), minor information is available for E. durans (Li et al., 2018). The E. durans LAB18S was previously isolated from a typical Brazilian soft cheese and exhibited some desirable probiotic properties in vitro (Pieniz et al., 2015). In addition, this strain thrives in selenium enriched medium, accumulating this element in the biomass (Pieniz et al., 2017). Further research is needed to prove its potential health benefits and application as a probiotic lineage in the industry. Thus, the aim of this study was to characterize the genome of $E$. durans LAB18S strain, searching for relevant genes associated with probiotic properties and selenoproteins, in addition to performing comparative analyzes with $E$. durans genomes from different isolation sites.

\section{Material and Methods}

\section{Genomic DNA preparation and high-throughput sequencing}

E. durans LAB18S was isolated from soft cheese, was retrieved from the collection of Laboratory of Applied Microbiology and Biochemistry (Universidade Federal do Rio Grande do Sul, Porto Alegre, Brazil). The strain was maintained as frozen stock cultures in Brain Heart Infusion (BHI, Oxoid) containing 20\% (v/v) glycerol. The bacterium was grown in MRS broth (de Man et al., 1960) at $37{ }^{\circ} \mathrm{C}$ at mid log phase $(8 \mathrm{~h})$.

E. durans LAB18S total DNA was extracted with phenolchloroform following usual procedures and purified using a Genomic DNA Clean \& Concentrator (Zymo Research). The quality and quantity of the DNA were assessed by spectrophotometry analysis using NanoDrop ${ }^{\mathrm{TM}}$ (Thermo Scientific) and fluorometry (Qubit ${ }^{\mathrm{TM}}$; Invitrogen), respectively. DNA fragment libraries were further prepared with $50 \mathrm{ng}$ of DNA using a Nextera ${ }^{\mathrm{TM}}$ XT DNA sample preparation kit and sequenced using an Illumina ${ }^{\mathrm{TM}}$ MiSeq System $(2 \times 250$ pairedend reads with the Illumina ${ }^{\mathrm{TM}} \mathrm{v} 2$ reagent kit), manufacturer's instructions.

After quality checking with FastQC software, reads were trimmed with Geneious software (version 10.2.3) (https:// www.geneious.com). The paired-end sequence reads were then assembled by de novo assembly using SPAdes 3.9.0 (Bankevich et al., 2012), and Geneious software version 10.2.3 followed by template-assisted assembly to the reference $E$. durans KLDS6.0933 (NZ_CP012366).

\section{Gene prediction and bioinformatics analysis}

Annotation NCBI Prokaryotic Genome Annotation Pipeline (PGAAP) was employed to identify coding sequences (CDS) based on the best-placed reference protein set. Similarly, to aid the gene prediction and annotation, E. durans genome were performed by RAST (Rapid Annotation Subsystem Technology) webservice (https://rast.nmpdr.org). Genes of interest had their annotation refined manually. This Whole Genome Shotgun project has been deposited at DDBJ/ENA/ GenBank under the accession NCVP00000000. The version described in this paper is version NCVP01000000.

Genes involved in the biosynthesis of secondary metabolites were analyzed in silico using the antiSMASH algorithm (Medema et al., 2011). We then used bSECISearch to predict candidates for bacterial SECIS elements and their putative coding genes with weight scores greater than the cutoff $(>30)$ in order to analyze the genome of E. durans LAB18S for full complement of selenoprotein genes (Zhang and Gladyshev, 2005). BLAST search (tblastn + blastx) was performed at NCBI to filter out false positive elements involved with selenium.

\section{Comparative analysis}

Antimicrobial resistance genes were identified using ResFinder 3.2 (Zankari et al., 2012) following the thresholds $60 \%$ identity over a length of $60 \%$ coverage, respectively. VirulenceFinder (Joensen et al., 2014) and PlasmidFinder (Caratoli et al., 2014) were used to predict potential virulence genes and plasmids, respectively. Identification thresholds were set at $60 \%$ identity over a minimum length of $60 \%$ for PlasmidFinder, and $85 \%$ identity over a length of $60 \%$ for VirulenceFinder.

Core genome Single Nucleotide Polymorphism (SNP) tree were performed using Parsnp v1.2 program included in Harvest (Treangen et al., 2014). A total of 31 E. durans genomes, one draft genome from this study and 30 genomes from previous studies obtained from the NCBI database were used (Table 1). Core genome SNPs of E. durans were identified, the reference genome was randomly selected using the parameter '-r!' and recombination regions were used (Treangen et al., 2014). An approximately maximum likelihood tree was constructed from concatenated SNPs using FastTree2 (Price et al., 2010), and interactive Tree Of Life (iTOL) v4 software (Letunik and Bork, 2019) were used for visualization and edition of the phylogenomic tree.

\section{Phenotypical characteristics}

E. durans $\mathrm{LAB} 18 \mathrm{~S}$ was evaluated for tolerance to acid $\mathrm{pH}$ and bile salts, $\beta$-galactosidase activity and growth on prebiotic oligosaccharides.

\section{Acid tolerance}

The resistance under acid conditions was investigated according to Erkkila and Petaja (2000) with some modifications. $E$. durans LAB18S cells were grown in BHI (Brain Heat Infusion broth; Oxoid) without shaking at $37^{\circ} \mathrm{C}$ for $24 \mathrm{~h}$. Then, the culture was standardized at an optical density $\left(\mathrm{OD}_{600}\right)=1.0 \pm 0.05$. One milliliter of standardized culture was added into tubes containing $10 \mathrm{~mL}$ of sterile BHI broth with the following $\mathrm{pH}$ values: 2.0, 3.0, 4.0 and 7.0 (adjusted 
with $\mathrm{HCl}$ ), in which $\mathrm{pH} 7.0$ was used as a control. Viable cell counts were determined after exposure to acidic condition for $0,1,2,3$ and $4 \mathrm{~h}$ at $37^{\circ} \mathrm{C}$. The experiment was performed in triplicate. Survival cell counts were expressed as $\log$ values of colony-forming units per $\mathrm{ml}(\mathrm{CFU} / \mathrm{mL})$.

\section{Bile tolerance test}

Growth in the presence of $0.3 \%(\mathrm{w} / \mathrm{v})$ oxbile was analyzed as described by Gilliland et al. (1984). Overnight grown $\left(16 \pm 2 \mathrm{~h}\right.$ at $\left.37^{\circ} \mathrm{C}\right)$ assay cultures were centrifuged at $8,000 \mathrm{x}$ $\mathrm{g}$ for $15 \mathrm{~min}$ at $4{ }^{\circ} \mathrm{C}$ and the pellet collected was resuspended in same volume of saline $(0.85 \% \mathrm{NaCl})$. Fresh BHI broth ( $5 \mathrm{ml}$ ), without ox bile with $\mathrm{pH} 7$ (for control), and BHI broth $(5 \mathrm{ml})$ containing $2.5,5,10$ and $15 \mathrm{mg} / \mathrm{mL}$ of ox bile was inoculated with $250 \mu \mathrm{l}(5 \%)$ of cell suspension. The growth was monitored hourly by measuring the OD at $600 \mathrm{~nm}$ using spectrophotometer. The survival percentage was calculated as follows: \% survival $=$ final $(\mathrm{OD}) / \operatorname{control}(\mathrm{OD}) \times 100$.
$\beta$-Galactosidase (BGL) activity

BGL activity was assayed by a modified procedure, based on the method of Hang and Woodams (1994). The source of BGL was a cell-free supernatant of E. durans LAB18S culture in BHI broth (Brain Heart Infusion) and sonicated LAB18S cells. Besides, this isolate was grown in BHI broth supplemented with $10 \mathrm{~g} / \mathrm{L}$ lactose and the same assay was performed. The reaction mixture $(200 \mu \mathrm{L})$ contained $90 \mu \mathrm{L}$ of citrate buffer ( $250 \mathrm{mM}, \mathrm{pH} 4.5), 10 \mu \mathrm{L}$ of $p$-nitrophenyl$\beta$-D-galactopyranoside (pNPGal; $4 \mathrm{mg} / \mathrm{mL}$ ), and $100 \mu \mathrm{L}$ of the enzyme source. After incubation at $37^{\circ} \mathrm{C}$ for $30 \mathrm{~min}$, the reaction was stopped by adding $1 \mathrm{~mL}$ of cold sodium carbonate buffer $(500 \mathrm{mM}, \mathrm{pH} 10)$. The activity of $\beta$-galactosidase was estimated spectrophotometrically by reading the absorbance of the liberated $p$-nitrophenol at $405 \mathrm{~nm}(\varepsilon=18,700)$. One unit $(\mathrm{U})$ of $\beta$-galactosidase activity was defined as the amount of enzyme required for the hydrolysis of $1 \mu \mathrm{mol}$ of substrate pNPGal per min, under the assay conditions.

Table 1 - Complementary information of Enterococcus durans genomes from NCBI.

\begin{tabular}{|c|c|c|c|c|c|}
\hline Species & Strain & GenBank assembly & Genome size (bp) & Contigs & n50 \\
\hline E. durans & $18 \mathrm{~S}$ & GCF_003945985.1 & 2760363 & 61 & 210893 \\
\hline E. durans & 4928STDY7071618 & GCA_902162045.1 & 3173223 & 140 & 69586 \\
\hline E. durans & 4928STDY7071587 & GCA_902161685.1 & 3129748 & 140 & 53780 \\
\hline E. durans & 4928STDY7071465 & GCA_902160745.1 & 2952049 & 115 & 66799 \\
\hline E. durans & 4928STDY7071468 & GCA_902160735.1 & 3049809 & 33 & 266845 \\
\hline E. durans & 4928STDY7071461 & GCA_902160695.1 & 2843396 & 99 & 68904 \\
\hline E. durans & 4928STDY7071424 & GCA_902160425.1 & 2993992 & 134 & 66221 \\
\hline E. durans & 4928STDY7071423 & GCA_902160385.1 & 2987662 & 135 & 66543 \\
\hline E. durans & 4928STDY7071358 & GCA_902159875.1 & 2937777 & 113 & 70649 \\
\hline E. durans & 4928STDY7071318 & GCA_902159725.1 & 3070184 & 143 & 59610 \\
\hline E. durans & 4928STDY7071647 & GCA_902159525.1 & 2965835 & 49 & 151918 \\
\hline E. durans & 4928STDY7071469 & GCA_902159215.1 & 3065464 & 56 & 207797 \\
\hline E. durans & 4928STDY7071427 & GCA_902159205.1 & 2986615 & 134 & 63841 \\
\hline E. durans & 4928STDY7071462 & GCA_902159195.1 & 3052558 & 42 & 228325 \\
\hline E. durans & 4928STDY7071385 & GCA_902159095.1 & 3126814 & 142 & 53818 \\
\hline E. durans & NCTC8129 & GCF_900447815.1 & 3259358 & 6 & 3126530 \\
\hline E. durans & NCTC8130 & GCF_900447695.1 & 3357395 & 8 & 3078716 \\
\hline E. durans & OSY-EGY & GCF_004330425.1 & 3230625 & 227 & 52003 \\
\hline E. durans & am_0171 & GCF_004167095.1 & 3002381 & 120 & 55320 \\
\hline E. durans & $\mathrm{C} 11$ & GCF_004102865.1 & 2988164 & 115 & 54843 \\
\hline E. durans & P16CLA28 & GCF_003796805.1 & 2886365 & 28 & 215484 \\
\hline E. durans & $\mathrm{AF} 1132 \mathrm{H}$ & GCF_003465125.1 & 3083830 & 215 & 34708 \\
\hline E. durans & FDAARGOS_396 & GCF_002554315.1 & 3395970 & 4 & 3104428 \\
\hline E. durans & BDGP3 & GCA_002277935.1 & 2988928 & 2 & 2983334 \\
\hline E. durans & F0321E104 & GCF_002077535.1 & 2931215 & 43 & 147275 \\
\hline E. durans & NBRC100479 & GCF_001544215.1 & 3017302 & 122 & 53575 \\
\hline E. durans & IQ23 & GCF_001455455.1 & 3125512 & 127 & 70907 \\
\hline E. durans & KLDS6.0930 & GCF_001267865.1 & 3071879 & 3 & 2867090 \\
\hline E. durans & KLDS6.0933 & GCF_001267395.1 & 3071804 & 3 & 2867028 \\
\hline E. durans & ATCC6056 & GCF_000406985.1 & 3153755 & 19 & 411581 \\
\hline E. durans & IPLA655 & GCF_000350465.1 & 3059052 & 145 & 73480 \\
\hline
\end{tabular}


Growth on prebiotic oligosaccharides

E. durans LAB18S cells were grown in $\mathrm{BHI}$ without shaking at $37^{\circ} \mathrm{C}$ for $24 \mathrm{~h}$. Then, the culture was inoculated $(1 \%, \mathrm{v} / \mathrm{v})$ in individual sterile vials containing M9 medium (5 g/L NH 4 Cl, $33.9 \mathrm{~g} / \mathrm{L} \mathrm{Na}_{2} \mathrm{HPO}_{4}, 15 \mathrm{~g} / \mathrm{L} \mathrm{KH}_{2} \mathrm{PO}_{4}$, and 2.5 $\mathrm{g} / \mathrm{L} \mathrm{NaCl}$ ), added with $10 \mathrm{~g} / \mathrm{L}$ of either glucose, lactose, FOS or GOS and incubated at $37^{\circ} \mathrm{C}$. The growth was monitored by measuring the OD at $600 \mathrm{~nm}$ using spectrophotometer.

\section{Results}

\section{Structure and general features of E. durans LAB18S genome}

The genome sequence of $E$. durans LAB18S was obtained using the Illumina ${ }^{\circledR}$ MiSeq system, and compared with the complete genome sequence of $E$. durans KLDS6.0933 (GenBank accession number CP012366.1). The complete genome of $E$. durans LAB18S is composed of a chromosome with $2,867,357 \mathrm{bp}$, GC content of $38 \%, 2,579$ CDSs, 108 RNAs and 180 pseudogenes (Table S1). By assembling the genome, a total of 82 contigs were obtained and a mean coverage of $31.7 \times$ giving reliability to the results. Comparatively, the reference strain (E. durans KLDS6.0933) has 2,867,028 bp and the $E$. durans LAB18S genome is slightly larger with additional $329 \mathrm{bp}$.

The genes were grouped into subsystems through the RAST webservice (Figure S1). In brief, there are 126 genes for cell wall and capsule; 342 genes for carbohydrate transport and metabolism, which contains 17 genes related with fructooligosaccharides (FOS) and raffinose utilization; 63 genes for virulence, disease and defense, which contains adhesion, bacteriocins, resistance to antibiotics and toxic compounds, invasion and intracellular resistance genes; 2 genes for phages and prophages; 58 for membrane transport; 219 for protein metabolism; 6 for dormancy and sporulation, and 69 for stress response.

\section{Genes associated with probiotics properties}

The $E$. durans LAB18S genome showed several genes that may be related with probiotic activity (Table 2). It encodes an S-layer protein (LIU RS11695), and two fibronectinbinding proteins (LIURS07910 and LIU RS10480), which may contribute to bacterial adherence. Besides, this genome carries an exopolysaccharide (EPS) cluster that could be related with improved adhesion properties and persistence in the gut. In addition, it also contains genes that can be associated to viability at lower $\mathrm{pH}\left(\mathrm{Na}^{+} / \mathrm{H}^{+}\right.$antiporters $)$and bile salt tolerance (Table 2). In this regard, E. durans LAB18S demonstrated ability to survive at $\mathrm{pH} 3.0$ and higher, and up to $15 \mathrm{mg} / \mathrm{mL}$ bile salts (Figure 1).

The potential for carbohydrate utilization was also analyzed and genes for fructooligosaccharide (FOS) and disaccharides utilization were found. Besides, the $\beta$-galactosidase (BGL) gene was identified in the genome (Table 2). These properties were confirmed by phenotypical assays showing the E. durans LAB18S has ability to growth on probiotic oligosaccharides FOS and GOS and produce BGL activity (Figure 2).

Table 2 - Genes associated with potential probiotic properties of E. durans LAB18S.

\begin{tabular}{|c|c|c|}
\hline Protein & Gene & Function \\
\hline \multicolumn{3}{|l|}{ Maintenance in the gastrointestinal tract } \\
\hline S-layer protein & $l b s$ & Improves adhesion properties and persistence in the gut \\
\hline Fibronectin-binding protein & $\operatorname{prtF}$ & Improves adhesion properties and persistence in the gut \\
\hline Heat-shock protein 33 & hsp33 & Improves persistence in the gut \\
\hline EPS cluster & eps $A B C D E$ & Improves adhesion properties and persistence in the gut \\
\hline $\mathrm{Na}^{+} / \mathrm{H}^{+}$antiporter & nhaC & Improves viability at low $\mathrm{pH}$ \\
\hline Cyclopropane-fatty-acyl-phospholipid synthase & $C f a$ & Key protein in bile salt tolerance \\
\hline \multicolumn{3}{|l|}{ Bacteriocins and toxin-antitoxins } \\
\hline Microcin cluster & $\operatorname{micJ} 25$ & Low molecular mass bacteriocins produced under stress conditions \\
\hline Enterocin A immunity protein & entI & Putative protection against the effect of bacteriocin enterocin A \\
\hline Colicin V precursor & $c v a C$ & Kills sensitive cells by disrupting their membrane potential \\
\hline Zeta-toxin & pSM19035 & Inhibits cell wall biosynthesis \\
\hline Toxin RelE & relE & $\begin{array}{c}\text { Cleaves translating mRNA in the ribossomal A-site upon aminoacid } \\
\text { starvation }\end{array}$ \\
\hline \multicolumn{3}{|l|}{ Resistance to heavy metals } \\
\hline Multi-copper oxidase & сиeO & Provides copper tolerance \\
\hline Copper-transporting efflux system & cusCFBA & Mediates resistance to copper and silver \\
\hline Cation efflux system protein CzcA & $c z c A$ & Provides resistance to cobalt, zinc and cadmium \\
\hline Mercuric reductase & merA & Provides resistance to mercury \\
\hline \multicolumn{3}{|l|}{ Carbohydrate utilization } \\
\hline Raffinose operon regulatory protein & $r a f R$ & Metabolism of fructooligosaccharides (FOS) and raffinose \\
\hline Lactose operon & $l a c Z Y A$ & Metabolism of lactose and galactose \\
\hline Maltodextrin phosphorylase & malP & Metabolism of maltodextrin and $\alpha-1,4$-glucans \\
\hline 4-alpha-glucanotransferase & malQ & Starch metabolism \\
\hline
\end{tabular}



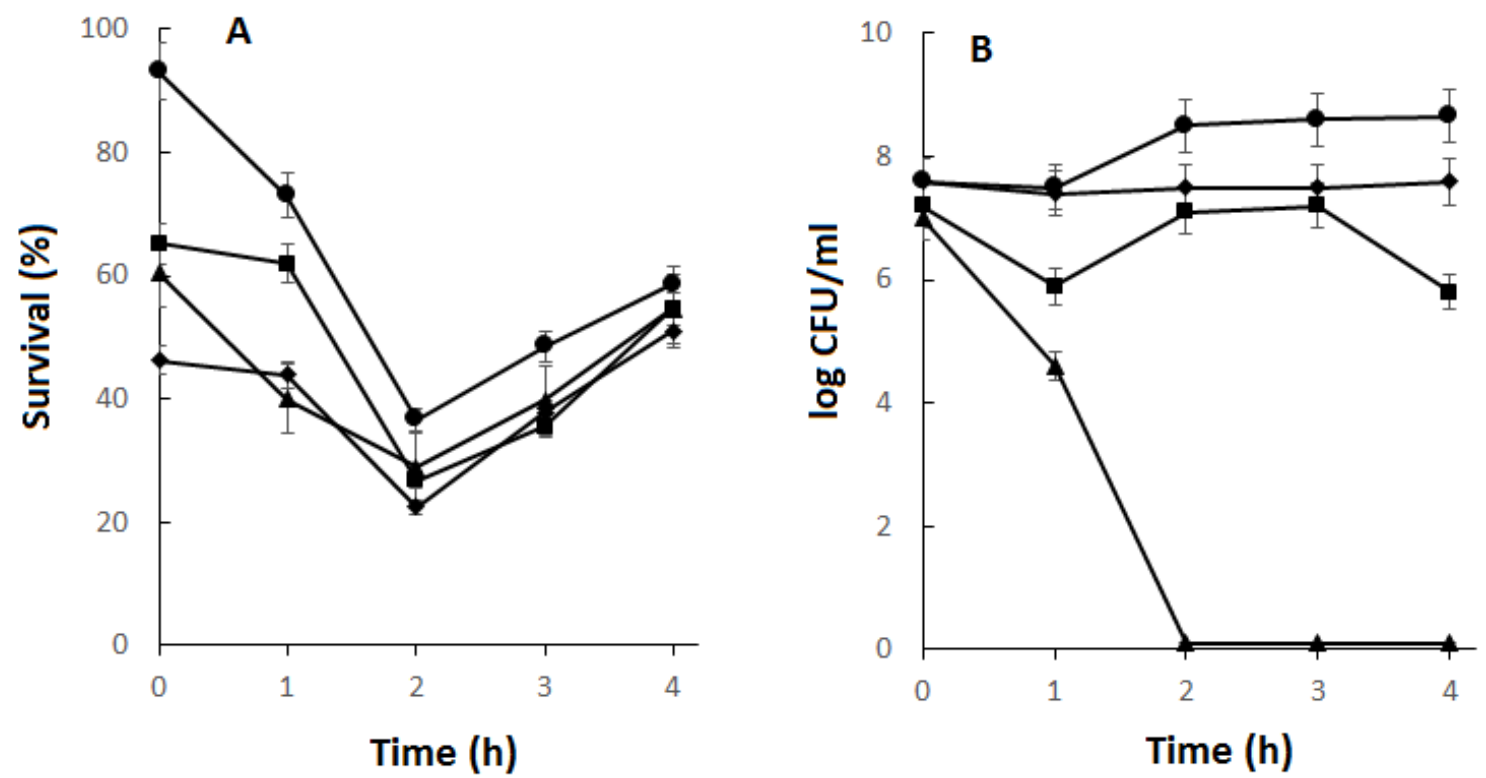

Figure 1 - Tolerance of $E$. durans LAB18S to bile salts and acid pH. (A) The strain was incubated for up to $4 \mathrm{~h}$ at $37^{\circ} \mathrm{C}$ in the presence of bile salts at concentrations $2.5 \mathrm{mg} / \mathrm{mL}(\bullet), 5.0 \mathrm{mg} / \mathrm{mL}(\bullet), 10 \mathrm{mg} / \mathrm{mL}(\boldsymbol{\Delta})$ or $15 \mathrm{mg} / \mathrm{mL}(\bullet)$. Results are expressed as percentage of surviving cells in comparison to incubation without bile salts used as a control. (B) The strain was incubated for up to $4 \mathrm{~h}$ at $37^{\circ} \mathrm{C}$ in pH $2(\mathbf{\Delta}), 3(\bullet), 4(\bullet)$ or 7 (•). Viable cell counts were monitored at each $1 \mathrm{~h}$ interval. Values are the means \pm standard deviations of three independent experiments.
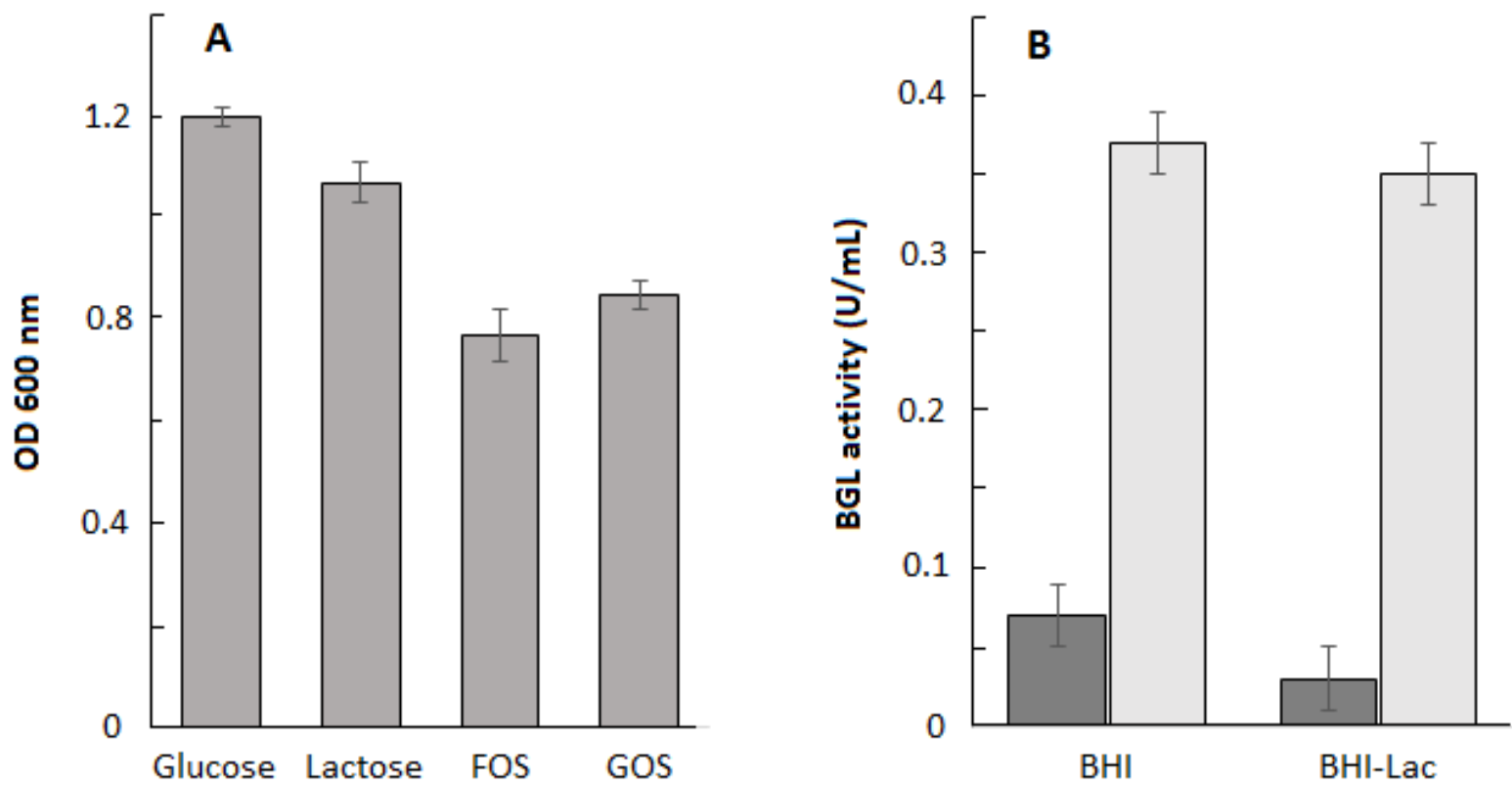

Figure 2 - Phenotypical characteristics of $E$. durans LAB18S. (A) Growth on different carbon sources. The strain was cultivated in medium containing 10 $\mathrm{g} / \mathrm{L}$ glucose, lactose, FOS or GOS and the cell density was estimated by $\mathrm{OD}_{600}$ after $24 \mathrm{~h}$ at $37^{\circ} \mathrm{C}$. (B) The $\beta$-galactosidase (BGL) activity was measured in the cell culture supernatant (dark gray bars) and cell lysates (pale gray bars) after growth in BHI or BHI supplemented with $10 \mathrm{~g} / \mathrm{L}$ lactose (BHI-Lac). Values are the means \pm standard deviations of three independent experiments.

Secondary metabolite analysis revealed the presence of genes associated with colicin $\mathrm{V}$, enterocin $\mathrm{A}$, and the small bacteriocin microcin J25 (Table 2). In agreement, the culture supernatant of $E$. durans LAB18S showed inhibitory haloes ranging 9-10 mm against strains of Listeria spp.. Furthermore, two genes of toxin-antitoxin proteins, namely RelE and Zeta-toxin, were also identified. The BLAST algorithm was used to align the deduced colicin $\mathrm{V}$ sequence of $E$. durans LAB18S with colicin $\mathrm{V}$ and colicin $\mathrm{V}$ production protein CvpA from other genera and species. This sequence is quite conserved among different species of Enterococcus, Bacillus and Carnobacterium and strain E. durans LAB18S (Figure S2).

\section{Genes related to selenoproteins}

The E. durans LAB18S genome contains seven genes involved in selenium metabolism (Table 3). Five genes encode typical selenoproteins, namely glutathione peroxidase $(g p x)$, thioredoxin reductase $(\operatorname{tr} x B 1, \operatorname{tr} x B 2)$, glycine reductase complex selenoprotein B $(\operatorname{grdB})$, and peroxiredoxin $(\operatorname{pr} X)$. Another two genes are related with selenium metabolism: 
Table 3 - Selenoprotein related genes predicted in E. durans LAB18S genome.

\begin{tabular}{|c|c|c|}
\hline Protein & Gene & Function \\
\hline \multicolumn{3}{|l|}{ Selenoproteins } \\
\hline Glutathione peroxidase & $g p x$ & Catalyzes the reduction of $\mathrm{H}_{2} \mathrm{O}_{2}$; protection against oxidative stress \\
\hline Thioredoxin reductase & $\operatorname{trx} B 1, \operatorname{trx} B 2$ & NADPH-depended oxidoreductase activity \\
\hline Glycine reductase complex & $\operatorname{grd} B$ & Active protein in the peroxidase reaction \\
\hline Peroxiredoxin & $\operatorname{prX}$ & $\begin{array}{l}\text { Antioxidant enzyme that uses thioredoxin (Trx) } \\
\text { to recharge after reducing } \mathrm{H}_{2} \mathrm{O}_{2}\end{array}$ \\
\hline \multicolumn{3}{|l|}{ Other selenium-related proteins } \\
\hline L-seryl-tRNA selenium transferase & selA & $\begin{array}{l}\text { Converts seryl-tRNA }(\mathrm{Sec}) \text { to selenocysteinyl-tRNA }(\mathrm{Sec}) \\
\text { required for selenoprotein biosynthesis }\end{array}$ \\
\hline Selenocysteine-specific elongation factor & selB & $\begin{array}{c}\text { Translation factor necessary for the incorporation } \\
\text { of selenocysteine into proteins }\end{array}$ \\
\hline YggS family pyridoxal phosphate & $y g g S$ & $\begin{array}{l}\text { Decomposes selenocysteine to alanine and elemental } \\
\text { Se or } \mathrm{H}_{2} \mathrm{Se} \text { during selenium metabolism }\end{array}$ \\
\hline
\end{tabular}

L-seryl-tRNA selenium transferase (selA) and YggS family pyridoxal phosphate $(y g g S)$.

In the analysis of the selenocysteine insertion sequence (SECIS) element, 1,274 hits were identified as candidates of bacterial SECIS (bSECIS)-like elements. These hits were divided into homologs of previously known selenoproteins (40 sequences) and candidates of selenoproteins (1,234 sequences). Then, optimal bSECIS elements and their predicted putative coding genes were identified as 26 known selenoproteins and 765 unknown bSECIS elements were detected. After the BLAST search was performed to filter out false positives, 12 bSECIS elements involved with selenium were identified. This indicates the ability of the E. durans LAB18S to produce selenoproteins.

After the BLAST search to filter out false positives, 12 bSECIS elements involved with selenium were identified. This indicates the ability of $E$. durans LAB18S to produce selenoproteins.

\section{Comparative analysis}

Virulence genes were not found in the E. durans genomes compared in this study, such as aggregation substance (agg), surface adhesins (esp, ace), sex pheromones (cob, cpd, ccf), D-alanylation of lipoteichoic acid (dlt), the lytic enzymes gelatinase $(\mathrm{gelE})$ and hyaluronidase $(h y l)$, and the toxin cytolysin ( $c y l A)$. Antimicrobial resistance was checked against the ResFinder database and genes associated with tetracycline resistance, namely tet $(\mathrm{M})$ and $\operatorname{tet}(\mathrm{O})$-like were found in seven genomes of E. durans, mostly from fecal origin (Table 4). Only three enterococci under study did not present any plasmids, including E. durans LAB18S. Besides the absence of plasmids, these three strains also showed no virulence and antimicrobial resistance genes. The 31 genomes of $E$. durans were clusterized into a phylogenetic tree (Figure 3). E. durans LAB18S has been clusterized with isolates NCTC8130, FDAARGOS_396 and ATCC 6056, which are of fecal origin, and NRBC10079, which lacks source information. None of these isolates showed antimicrobial resistance or virulence genes. The presence of plasmids was found in these isolates, excepting for E. durans LAB18S (Table 4).

\section{Discussion}

Complete knowledge of genome sequences may allow a precise genetic analysis of probiotic bacteria. This includes the genetic features that can be associated with beneficial effects and those potentially associated with undesirable characteristics. The genus Enterococcus contains strains associated with severe infections, while other strains form part of the commensal human microbiome of the mouth, skin, and gut. Some strains have probiotic properties, including $E$. durans (Liaskovs'kyı̌ et al., 2008; Li et al., 2018). Interestingly, virulence is very different among enterococci derived from community or hospital environments, which appears to be associated to some strain-specific genetic features (Douillard and de Vos, 2014). Thus, the study of whole genomes is relevant to acquire information on the potential benefits and drawbacks. In this work, the genome of E. durans LAB18S isolated from Minas Frescal cheese showed some desirable characteristics for a probiotic strain.

The survival of probiotic bacteria under gastrointestinal tract conditions has been extensively studied. Probiotics, after ingestion, are exposed to the acidic conditions and the activity of digestive enzymes of the stomach. E. durans LAB18S is equipped with a gene coding for $\mathrm{Na}^{+} / \mathrm{H}^{+}$antiporter, contributing to regulate intracellular $\mathrm{pH}$ (Guo et al., 2015). The reduction of bacterial survival in the gut may be due to secretion of bile that breaks the microbial cell membrane, and tolerance to bile salt concentrations between 0.15 and $0.5 \%$ has been recommended for probiotics (Lavermicocca et al., 2008). The gene encoding cyclopropane-fatty-acyl-phospholipid synthase (HUO 05315), present in the genome of E. durans LAB18S, might be associated with bile salt tolerance. Comparative proteomic studies on Lactobacillus plantarum identified this enzyme as a key protein in bile tolerance (Hamon et al., 2011). Bile salt hydrolase identified in the genome of $E$. durans KLDS6.0933, has been also associated with cholesterol removal ability (Li et al., 2018).

Adhesive properties can prolong the contact between bacteria and the host and therefore enhance the desired probiotic effect (Botta et al., 2014). Although mucus-binding proteins and adhesion genes are absent, E. durans LAB18S 
Table 4 - Comparative analysis of the presence of virulence genes, antimicrobial resistance genes and plasmids of $31 E$. durans genomes.

\begin{tabular}{|c|c|c|c|c|c|c|c|c|c|c|c|c|}
\hline \multirow{2}{*}{ Species } & \multirow{2}{*}{ Strain } & \multirow{2}{*}{ Origin } & \multicolumn{2}{|c|}{ Resistance } & \multirow{2}{*}{ - Virulence } & \multicolumn{7}{|c|}{ Plasmids } \\
\hline & & & $\operatorname{tet}(\mathrm{M})$ & $\operatorname{tet}(\mathrm{O})$ & & rep 1 & rep 2 & rep4 & rep 11 & rep 18 & repUS1 & repUS15 \\
\hline $\begin{array}{l}\text { Enterococcus } \\
\text { durans }\end{array}$ & NCTC8129 & Unknown & & & & & & & & & & \\
\hline $\begin{array}{l}\text { Enterococcus } \\
\text { durans }\end{array}$ & NCTC8130 & Unknown & & & & & & & & & & \\
\hline $\begin{array}{l}\text { Enterococcus } \\
\text { durans }\end{array}$ & P16CLA28 & $\begin{array}{l}\text { Cloaca } \\
\text { (Gallus } \\
\text { gallus) }\end{array}$ & & & & & & & & & & \\
\hline $\begin{array}{l}\text { Enterococcus } \\
\text { durans }\end{array}$ & F0321E104 & $\begin{array}{l}\text { Feces (Bos } \\
\text { taurus) }\end{array}$ & & & & & & & & & & \\
\hline $\begin{array}{l}\text { Enterococcus } \\
\text { durans }\end{array}$ & LAB18S & $\begin{array}{l}\text { Frescal } \\
\text { cheese }\end{array}$ & & & & & & & & & & \\
\hline $\begin{array}{l}\text { Enterococcus } \\
\text { durans }\end{array}$ & KLDS6.0930 & Water & & & & & & & & & & \\
\hline $\begin{array}{l}\text { Enterococcus } \\
\text { durans }\end{array}$ & KLDS6.0933 & Water & & & & & & & & & & \\
\hline $\begin{array}{l}\text { Enterococcus } \\
\text { durans }\end{array}$ & IQ23 & Cheese & & & & & & & & & & \\
\hline $\begin{array}{l}\text { Enterococcus } \\
\text { durans }\end{array}$ & AF1132H & $\begin{array}{l}\text { Feces (Homo } \\
\text { sapiens) }\end{array}$ & & & & & & & & & & \\
\hline $\begin{array}{l}\text { Enterococcus } \\
\text { durans }\end{array}$ & ATCC6056 & $\begin{array}{l}\text { Feces (Homo } \\
\text { sapiens) }\end{array}$ & & & & & & & & & & \\
\hline $\begin{array}{l}\text { Enterococcus } \\
\text { durans }\end{array}$ & IPLA655 & Cheese & & & & & & & & & & \\
\hline $\begin{array}{l}\text { Enterococcus } \\
\text { durans }\end{array}$ & $\mathrm{C} 11$ & Kimchi & & & & & & & & & & \\
\hline $\begin{array}{l}\text { Enterococcus } \\
\text { durans }\end{array}$ & OSY-EGY & $\begin{array}{l}\text { Egyptian hard } \\
\text { Cheese }\end{array}$ & & & & & & & & & & \\
\hline $\begin{array}{l}\text { Enterococcus } \\
\text { durans }\end{array}$ & am_0171 & $\begin{array}{l}\text { Feces }(\text { Homo } \\
\text { sapiens })\end{array}$ & & & & & & & & & & \\
\hline $\begin{array}{l}\text { Enterococcus } \\
\text { durans }\end{array}$ & BDGP3 & $\begin{array}{c}\text { Feces } \\
\text { (Drosophila } \\
\text { melanogaster) }\end{array}$ & & & & & & & & & & \\
\hline $\begin{array}{l}\text { Enterococcus } \\
\text { durans }\end{array}$ & 4928STDY7071618 & $\begin{array}{l}\text { Feces (Homo } \\
\text { sapiens) }\end{array}$ & & & & & & & & & & \\
\hline $\begin{array}{l}\text { Enterococcus } \\
\text { durans }\end{array}$ & 4928STDY7071587 & $\begin{array}{l}\text { Feces (Homo } \\
\text { sapiens) }\end{array}$ & & & & & & & & & & \\
\hline $\begin{array}{l}\text { Enterococcus } \\
\text { durans }\end{array}$ & 4928STDY7071465 & $\begin{array}{l}\text { Feces (Homo } \\
\text { sapiens) }\end{array}$ & & & & & & & & & & \\
\hline $\begin{array}{l}\text { Enterococcus } \\
\text { durans }\end{array}$ & 4928STDY7071468 & $\begin{array}{l}\text { Feces (Homo } \\
\text { sapiens) }\end{array}$ & & & & & & & & & & \\
\hline $\begin{array}{l}\text { Enterococcus } \\
\text { durans }\end{array}$ & 4928STDY7071461 & $\begin{array}{l}\text { Feces }(\text { Homo } \\
\text { sapiens) }\end{array}$ & & & & & & & & & & \\
\hline $\begin{array}{l}\text { Enterococcus } \\
\text { durans }\end{array}$ & 4928STDY7071424 & $\begin{array}{l}\text { Feces (Homo } \\
\text { sapiens) }\end{array}$ & & & & & & & & & & \\
\hline $\begin{array}{l}\text { Enterococcus } \\
\text { durans }\end{array}$ & 4928STDY7071423 & $\begin{array}{l}\text { Feces (Homo } \\
\text { sapiens) }\end{array}$ & & & & & & & & & & \\
\hline $\begin{array}{l}\text { Enterococcus } \\
\text { durans }\end{array}$ & 4928STDY7071358 & $\begin{array}{c}\text { Feces }(\text { Homo } \\
\text { sapiens) }\end{array}$ & & & & & & & & & & \\
\hline $\begin{array}{l}\text { Enterococcus } \\
\text { durans }\end{array}$ & 4928STDY7071318 & $\begin{array}{l}\text { Feces (Homo } \\
\text { sapiens) }\end{array}$ & & & & & & & & & & \\
\hline $\begin{array}{l}\text { Enterococcus } \\
\text { durans }\end{array}$ & 4928STDY7071647 & $\begin{array}{c}\text { Feces (Homo } \\
\text { sapiens) }\end{array}$ & & & & & & & & & & \\
\hline $\begin{array}{l}\text { Enterococcus } \\
\text { durans }\end{array}$ & 4928STDY7071469 & $\begin{array}{c}\text { Feces (Homo } \\
\text { sapiens) }\end{array}$ & & & & & & & & & & \\
\hline $\begin{array}{l}\text { Enterococcus } \\
\text { durans }\end{array}$ & 4928STDY7071427 & $\begin{array}{l}\text { Feces }(\text { Homo } \\
\text { sapiens) }\end{array}$ & & & & & & & & & & \\
\hline
\end{tabular}


Table 4 - Cont.

\begin{tabular}{|c|c|c|c|c|c|c|c|c|c|c|c|c|}
\hline \multirow{2}{*}{ Species } & \multirow{2}{*}{ Strain } & \multirow{2}{*}{ Origin } & \multicolumn{2}{|c|}{ Resistance } & \multirow{2}{*}{-Virulence } & \multicolumn{7}{|c|}{ Plasmids } \\
\hline & & & $\operatorname{tet}(\mathrm{M})$ & $\operatorname{tet}(\mathrm{O})$ & & rep 1 & rep 2 & rep4 & rep 11 & rep 18 & repUS1 & repUS15 \\
\hline $\begin{array}{l}\text { Enterococcus } \\
\text { durans }\end{array}$ & 4928STDY7071462 & $\begin{array}{c}\text { Feces }(\text { Homo } \\
\text { sapiens) }\end{array}$ & & & & & & & & & & \\
\hline $\begin{array}{l}\text { Enterococcus } \\
\text { durans }\end{array}$ & 4928STDY7071385 & $\begin{array}{c}\text { Feces (Homo } \\
\text { sapiens) }\end{array}$ & & & & & & & & & & \\
\hline $\begin{array}{l}\text { Enterococcus } \\
\text { durans }\end{array}$ & FDAARGOS_396 & $\begin{array}{c}\text { Feces (Homo } \\
\text { sapiens) }\end{array}$ & & & & & & & & & & \\
\hline $\begin{array}{l}\text { Enterococcus } \\
\text { durans }\end{array}$ & NBRC 100479 & Unkwnown & & & & & & & & & & \\
\hline
\end{tabular}

Black boxes indicate the presence of resistance genes, dark gray boxes indicate the presence of plasmids, light gray lines indicate the strains that were negative for virulence genes, antimicrobial resistance genes and plasmids.

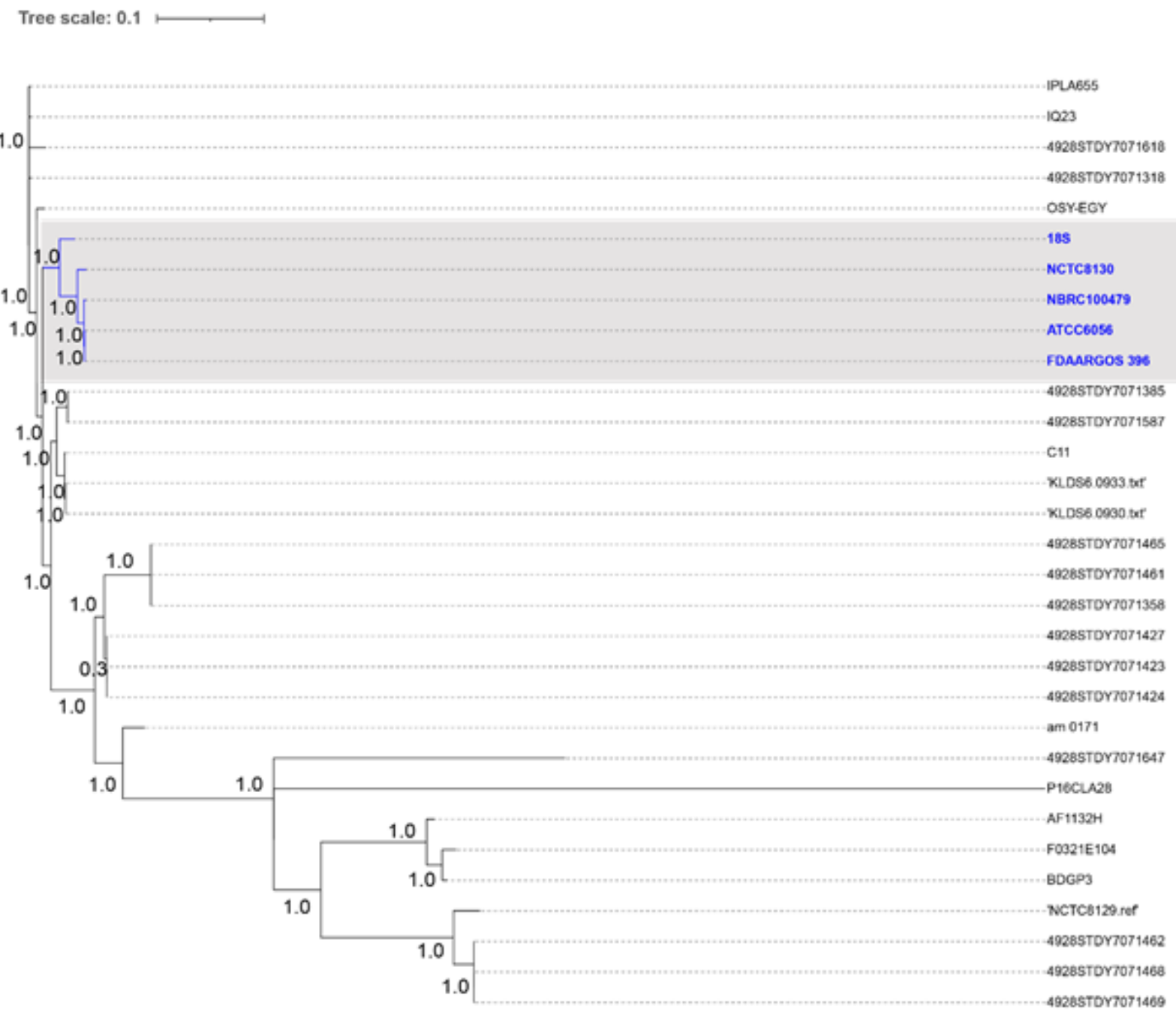

Figure 3 - Core genome SNP tree of 31 E. durans. The phylogenomic reconstruction was built using Parsnp and Fast tree 2. The percentage of the reference that is covered by core alignments was above $60 \%$. Strains related with $E$. durans LAB $18 \mathrm{~S}$ are highlighted in the grey box.

genome presents an S-layer protein (LIURS 11695), and fibronectin-binding proteins (LIURS 07910 and LIURS 10480), which may contribute to bacterial adherence. In addition, a gene encoded aggregation-promoting factor (LIURS 03835) was also identified, suggesting that this strain can bind to receptors in the gut environment (Senan et al., 2015). Some EPS produced by probiotics can improve its adhesion properties and its persistence in the gut (RuasMadiedo et al., 2006), and the E. durans LAB18S genome carries an EPS cluster. All these genetic elements corroborate to the potential adhesive characteristics of $E$. durans LAB18S.

The production of bacteriocins by probiotic strains has been recognized as a desirable feature (Hegarty et al., 2016). Analysis for secondary metabolite clusters of E. durans 
LAB18S genome revealed the presence of genes associated with the synthesis of microcin $\mathrm{J} 25$, colicin $\mathrm{V}$ and enterocin A, which may endow competitive advantages to combat pathogenic bacteria. The inhibitory activity of E. durans LAB18S against Listeria spp. agrees with the typical antilisterial activity of Enterococcus bacteriocins (Rocha et al., 2019). Colicin V is produced by many strains of Escherichia coli and its precursor peptide is similar to some bacteriocins of the Enterobacteriaceae family, which fits the definition of class II bacteriocins from Gram-positive bacteria (Håvarstein et al., 1994). The transfer of genes encoding bacteriocins from Gram-negative bacteria, such as colicin V, to food-grade lactic acid bacteria (LAB) host has been described (Langa et al., 2017). In this regard, Horn et al. (2004) were the first to show the coproduction of nisin and colicin V in Lactococcus lactis as a host enhancing the antimicrobial activity against both Gram-positive and Gram-negative bacteria.

The E. durans LAB18S genome contains genes of toxinantitoxin systems, which have been associated with survival under stress conditions (Fernández-García et al., 2016). Zetatoxin is bactericidal for Bacillus subtilis and bacteriostatic for $E$. coli, while the toxin RelE degrades mRNA at specific sequences when it is bound to the ribosomal A site (Pedersen et al., 2003). As a concern, the presence of omega/epsilon/zeta toxin-antitoxin system seems to stabilize plasmids carrying vanA in E. faecium and E. faecalis resistant to vancomycin (Fernández-Gracía et al., 2016).

Genes related to the metabolism of molecules associated with prebiotic properties were also identified. The strain LAB18S presented genes related to the use of frutooligosaccharides (FOS), a non-digestible dietary component that undergo selective colonic fermentation. FOS cause significant changes in the composition of the gut microbiota, increasing the numbers of potentially healthpromoting bacteria and reducing potentially harmful species, respectively (Slavin, 2013). Cultivation of E. durans LAB18S on FOS revealed an increased number of overexpressed proteins, including L-asparaginase and arginine deiminase, two enzymes of clinical importance for the treatment of cancer (Comerlato et al., 2020). The BGL gene was also detected in the genome. This enzyme is produced by several LAB with both hydrolase and transglycosylase activities, beneficial from technological and health point of views for applications as probiotic cultures in dairy industry or synthesis of prebiotic GOS (Meira et al., 2012). Because they are not digested by humans, GOS represents a rich source of substrate for probiotic organisms, including Enterococcus (Park and Oh, 2010).

Selenium is an essential metalloid required for the expression of selenoproteins. It was previously observed that E. durans LAB18S bioaccumulates selenium when grown in medium containing $\mathrm{Na}_{2} \mathrm{SeO}_{3}$ (Pieniz et al., 2017). Selenium was mainly found as selenoproteins, reaching 2.6 $\mathrm{mg} / \mathrm{g}$ biomass. Selenoprotein genes, to insert SEC into UGA codons, have developed a stem-loop shaped RNA structure, called SECIS. These SECIS elements are located downstream of the Sec UGA codons in bacteria. Through a computer program we were able to identify conserved structural characteristics of these structures. Bacterial SECISearch recognize a bacterial consensus SECIS element in sequence databases and the results indicate the ability of the E. durans LAB18S to produce selenoproteins. Selenium antioxidant properties stimulates the activity of some antioxidant enzymes, such as glutathione peroxidase, thioredixin reductase, and iodothyronine deiodinase, which contain selenocysteine (Lin et al., 2015). One biological form of Se has been identified as selenocysteine (Sec) (Hatfield and Gladyshev, 2002), but selenium could form selenomethionine (SeMet) by replacing sulfur in methionine and thus could be incorporated into proteins instead of methionine (Schrauzer, 2000). Although some microorganisms are capable of transforming high concentrations of selenium into selenate and selenite, only few studies on selenite uptake and biotransformation have been conducted with probiotic microorganisms (Zhang et al., 2009; Pieniz et al., 2017). Comparative genomic analyses were performed in order to identify new genes associated to Se utilization in Enterococcus faecalis. Seven candidate genes for selenoproteins were identified (Zhang et al., 2008), the same number found in this study.

Enterococci may have resistance to various antibiotics, due to their innate resistance to widely used antibiotics such as penicillin or to their ability to easily acquire antimicrobial resistance, especially by horizontal gene transfer. Horizontal transfer of antimicrobial resistance in enterococci has been associated with mobile genetic elements, such as plasmids and transposons (Palmer et al., 2012; Beukers et al., 2015). Resistance to tetracycline in Enterococcus spp. is frequently associated with the resistance genes tet $(\mathrm{M})$ and tet $(\mathrm{O})$ (Roberts, 2005; Anderson et al., 2016). Recently, a PCR-based plasmid classification system has been established by targeting specific replicon initiation genes (rep) of plasmid DNA. Rep-family, already found in the genus Enterococcus, may confer multiple antibiotic resistance as well as the mechanism of stabilization of toxin-antitoxin plasmids (Zankari et al., 2012; Bonacina et al., 2017). The absence of such genetic elements in E. durans LAB18S reinforce its promising as probiotic strain. Another recent study concludes that a cheese isolate E. faecalis does not represent a substantial reservoir of antimicrobial resistance and virulence when compared to clinical strains (Silvetti et al., 2019). The E. durans LAB18S genome was more closely to human feces genomes, which can be explained in part because enterococci are enteric bacteria commonly associated with the gastrointestinal tract of animals. In this regard, many probiotic lineages have been identified from animals or human feces (Hanchi et al., 2018; Nagpal et al., 2018; Bazireh et al., 2020).

In summary, the genome of $E$. durans LAB $18 \mathrm{~S}$ presents a variety of genes that can be associated with probiotic properties, such as adhesion properties, viability at lower $\mathrm{pH}$, bile salt tolerance, production of bacteriocins, and utilization of prebiotic molecules. Besides, this strain presents genes encoding for known selenoproteins, which should contribute to the antioxidant properties. In comparison with other $E$. durans genomes, E. durans LAB18S was the only food isolate with absence of plasmids, virulence and antimicrobial resistance genes. E. durans LAB18S exhibited a probiotic potential and its potential health benefit and application as probiotic strain in the feed industry merits future investigation. This work significantly improved the knowledge on the genetic characteristics of this promising strain. 


\section{Acknowledgements}

This work received financial support from CAPES, CNPq (grant 307455/2013-0) and FINEP Mais Água (grant 0112.0113).

\section{Conflict of Interest}

The authors declare no conflicts of interest.

\section{Author Contributions}

CBC performed the experiments and data analysis and wrote the manuscript, JP and FMS performed data analysis and writing, ACR, AMPV and FQM, performed experiments and data analysis, $\mathrm{AB}$ conceived the idea, participated in design and coordination, and secured funding. All authors read and approved the final manuscript.

\section{References}

Anderson AC, Jonas D, Huber I, Karygianni L, Wölber J, Hellwig E, Arweiler N, Vach K, Wittmer A and Al-Ahmad A (2016) Enterococcus faecalis from food, clinical specimens, and oral sites: Prevalence of virulence factors in association with biofilm formation. Front Microbiol 6:1534.

Bankevich A, Nurk S, Antipov D, Gurevich AA, Dvorkin M, Kulikov AS, Lesin VM, Nikolenko SI, Pham SON, Prjibelski AD et al. (2012) SPAdes: A new genome assembly algorithm and its applications to single-cell sequencing. J Comput Biol 19:455-477.

Bazireh H, Shariati P, Azimzadeh Jamalkandi S, Ahmadi A and Boroumand MA (2020) Isolation of novel probiotic Lactobacillus and Enterococcus strains from human salivary and fecal sources. Front Microbiol 11:597946.

Beukers AG, Zaheer R, Cook SR, Stanford K, Chaves AV, Ward MP and McAllister TA (2015) Effect of in-feed administration and withdrawal of tylosin phosphate on antibiotic resistance in enterococci isolated from feedlot steers. Front Microbiol 6:483.

Bonacina J, Suárez N, Hormigo R, Fadda S, Lechner M and Saavedra L (2017) A genomic view of food-related and probiotic Enterococcus strains. DNA Res 24:11-24.

Botta C, Langerholc T, Cencic A and Cocolin L (2014) In vitro selection and characterization of new probiotic candidates from table olive microbiota. PLoS One 9:e94457.

Byappanahalli MN, Nevers MB, Korajkic A, Stanley ZR and Harwood VJ (2012) Enterococci in the environment. Microbiol Mol Biol Rev 76:685-706.

Carattoli A, Zankari E, García-Fernández A, Voldby LM, Lund O, Villa L, Aarestrup FM and Hasman H (2014) In silico detection and typing of plasmids using PlasmidFinder and plasmid multilocus sequence typing. Antimicrob Agents Chemother 58:3895-3903.

Clemente JC, Ursell LK, Partry LW and Knight R (2012) The impact of the gut microbiota on human health: An integrative view. Cell 148:1258-1270.

Comerlato CB, Zhang X, Walker K, Brandelli A and Figeys D (2020) Comparative proteomic analysis reveals metabolic variability of probiotic Enterococcus durans during aerobic and anaerobic cultivation. J Proteomics 220:103764.

de Man JC, Rogosa M and Sharpe ME (1960) Medium for the cultivation of lactobacilli. J Appl Bacteriol 23:130-135.

Douillard FP and de Vos WM (2014) Functional genomics of lactic acid bacteria: From food to health. Microb Cell Fact 13:S8.

Erkkila S and Petaja E (2000) Screening of commercial meat starter cultures at low $\mathrm{pH}$ and in the presence of bile salts for potential probiotic use. Meat Sci 55:297-300.
Fernández-García L, Blasco L, Lopez M, Bou G, García-Contreras $\mathrm{R}$, Wood $\mathrm{T}$ and Tomas M (2016) Toxin-antitoxin systems in clinical pathogens. Toxins (Basel) 8:227.

Franz CM, Huch M, Abriouel H, Holzapfel W and Gálvez A (2011) Enterococci as probiotics and their implications in food safety. Int J Food Microbiol 151:125-140.

Galano E, Mangiapane E, Bianga J, Palmese A, Pessione E, Szpunar J, Lobinski R and Amoresano A(2013) Privileged incorporation of selenium as selenocysteine in Lactobacillus reuteri proteins demonstrated by selenium-specific images and proteomics. Mol Cell Proteomics 12:2196-2204.

Gilliland SE, Staley TE and Bush LJ (1984) Importance of bile tolerance of Lactobacillus acidophilus used as dietary adjunct. J Dairy Sci 67:3045-3051.

Guo L, Li T, Tang Y, Yang L and Huo G (2015) Probiotic properties of Enterococcus strains isolated from traditional naturally fermented cream in China. Microb Biotechnol 9:737-745.

Hamon E, Horvatovich P, Izquierdo E, Bringel F, Marchioni E, Aoudé-Werner D and Ennahar S (2011) Comparative proteomic analysis of Lactobacillus plantarum for the identification of key proteins in bile tolerance. BMC Microbiol 11:63.

Hanchi H, Mottawea W, Sebei K and Hammami R (2018) The genus Enterococcus: between probiotic potential and safety concerns - An update. Front Microbiol 9:1791.

Hang YD and Woodams EE (1994) Apple pomace: A potential substrate for production of $\beta$-glucosidase by Aspergillus foetidus. LWT Food Sci Technol 27:587-589.

Hatfield DL, Berry MJ and Gladyshev VN (2006) Selenium - Its molecular biology and role in human health. 2nd edition. Springer, New York, $444 \mathrm{p}$.

Hatfield DL and Gladyshev VN (2002) How selenium has altered our understanding of the genetic code. Mol Cell. Biol 22:3565-3576.

Håvarstein LS, Holo H and Nes IF (1994) The leader peptide of colicin $\mathrm{V}$ shares consensus sequences with leader peptides that are common among peptide bacteriocins produces by Gram positive bacteria. Microbiology (Reading) 140:2383-2389.

Hegarty JW, Guinane CM, Ross RP, Hill C and Cotter PD (2016) Bacteriocin production: A relatively unharnessed probiotic trait? F1000Res 5:2587.

Hill C, Guarner F, Reid G, Gibson GR, Merenstein DJ, Pot B, Morelli L, Canani RB, Flint HJ, Salminen S et al. (2014) Expert consensus document: The International Scientific Association for Probiotics and Prebiotics (consensus statement on the scope and appropriate use of the term probiotic. Nat Rev Gastroenterol Hepatol 11:506-514.

Horn N, Fernandez A, Dodd HM, Gasson MJ and Rodriguez JM (2004) Nisin-controlled production of pediocin PA-1 and colicin V in nisin- and non-nisin-producing Lactococcus lactis strains. Appl Environ Microbiol 70:5030-5032.

Joensen KG, Scheutz F, Lund O, Hasman H, Kaas RS, Nielsen EM and Aarestrup FM (2014) Real-time whole-genome sequencing for routine typing, surveillance, and outbreak detection of verotoxigenic Escherichia coli. J Clin Microbiol 52:1501-1510.

Ladero V, Linares DM, del Rio B, Fernandez M, Martin MC and Alvarez MA (2013) Draft genome sequence of the tyramine producer Enterococcus durans strain IPLA 655. Genome Announc 1:e00265-13.

Langa S, Arqués J, Medina M and Landete J (2017) Coproduction of colicin $\mathrm{V}$ and lactic acid bacteria bacteriocins in lactococci and enterococci strains of biotechnological interest. J Appl Microbiol 122:1159-1167.

Lavermicocca P, Valerio F, Lonigro SL, Di Leo A and Visconti A (2008) Antagonistic activity of potential probiotic lactobacilli against the ureolytic pathogen Yersinia enterocolitica. Curr Microbiol 56:175-181. 
Letunic I and Bork P (2019) Interactive Tree Of Life (iTOL) v4: Recent updates and new developments. Nucleic Acids Res 47:W256-W259.

Li B, Evivie SE, Jin D, Meng Y, Li N, Yan F, Huo G and Liu F (2018) Complete genome sequence of Enterococcus durans KLDS6.0933, a potential probiotic strain with high cholesterol removal ability. Gut Pathog 10:32.

Liaskovs'kyĭ TM, Pidhors'kyॅ VS, Kovalenko NK, Harmasheva IL and Muchnyk FV (2008) Identification of probiotic lactic acid bacteria strains. Mikrobiol Z 70:3-9.

Lin HC, Ho SC, Chen YY, Khoo KH, Hsu PH and Yen HCS (2015) CRL2 aids elimination of truncated selenoproteins produced by failed UGA/Sec decoding. Science 349:91-95.

Martín R and Langella P (2019) Emerging health concepts in the probiotics field: Streamlining the definitions. Front Microbiol 10:1047.

Medema MH, Blin K, Cimermancic P, de Jager V, Zakrzewski P, Fischbach MA, Weber T, Takano E and Breitling R (2011) antiSMASH: Rapid identification, annotation and analysis of secondary metabolite biosynthesis gene clusters in bacterial and fungal genome sequences. Nucleic Acids Res 39:339-346.

Meira SMM, Helfer VE, Velho RV, Lopes FC and Brandelli A(2012) Probiotic potential of Lactobacillus spp. isolated from Brazilian regional ovine cheeses. J Dairy Res 79:119-127.

Nagpal R, Wang S, Ahmadi S, Hayes J, Gagliano J, Subashchandrabose S, Kitzman DW, Becton T, Read R and Yadav H (2018) Human-origin probiotic cocktail increases short-chain fatty acid production via modulation of mice and human gut microbiome. Sci Rep 8:12649.

Palmer KL, Godfrey P, Griggs A, Kos VN, Zucker J, Desjardins C, Cerqueira G, Gevers D, Walker S, Wortman J et al. (2012) Comparative genomics of enterococci: variation in Enterococcus faecalis, clade structure in E. faecium, and defining characteristics of E. gallinarum and E. casseliflavus. mBio 3:e0318-11.

Park AR and Oh DK (2010) Galacto-oligosaccharide production using microbial beta-galactosidase: Current state and perspectives. Appl Microbiol Biotechnol 85:1279-1286.

Pedersen K, Zavialov AV, Pavlov M, Elf J, Gerdes K and Ehrenberg M (2003) The bacterial toxin RelE displays codon-specific cleavage of mRNAs in the ribosomal A site. Cell 112:131-140.

Pieniz S, Moura TM, Cassenego AP, Andreazza R, Frazzon AP, Oliveira FAO and Brandelli A (2015) Evaluation of resistance genes and virulence factors in a food isolated Enterococcus durans with potential probiotic effect. Food Control 51:49-54.

Pieniz S, Andreazza R, Mann MB, Camargo FAO and Brandelli A (2017) Bioaccumulation and distribution of selenium in Enterococcus durans. J Trace Elem Med Biol 40:37-45.

Price MN, Dehal PS and Arkin AP (2010) FastTree 2 - Approximately maximum-likelihood trees for large alignments. PLoS One 5:e9490.

Roberts MC (2005) Update on acquired tetracycline resistance genes. FEMS Microbiol Lett 245:195-203.

Rocha KR, Perini HF, Souza CM, Schueler J, Tosoni NF, Furlaneto MC and Furlaneto-Maia L (2019) Inhibitory effect of bacteriocins from enterococci on developing and preformed biofilms of Listeria monocytogenes, Listeria inovanii and Listeria innocua. World J Microbiol Biotechnol 35:96.

Ruas-Madiedo P, Gueimonde M, Margolles A, de los Reyes-Gavilán CG and Salminen S (2006) Exopolysaccharides produced by probiotic strains modify the adhesion of probiotics and enteropathogens to human intestinal mucus. J Food Prot 69:2011-2015.

Schrauzer GN (2000) Selenomethionine: a review of its nutritional significance, metabolism and toxicity. J Nutr 130:1653-1656.

Senan S, Prajapati JB and Joshi CG (2015) Whole-genome based validation of the adaptive properties of Indian origin probiotic Lactobacillus helveticus MTCC5463. J Sci Food Agric 95:321328.

Silvetti T, Morandi S and Brasca M (2019) Does Enterococcus faecalis from traditional raw milk cheeses serve as a reservoir of antibiotic resistance and pathogenic traits? Foodborne Pathog Dis 16:359-367.

Slavin J (2013) Fiber and prebiotics: Mechanisms and health benefits. Nutrients 5:1417-1435.

Treangen TJ, Ondov BD, Koren S and Phillippy AM (2014) The Harvest suite for rapid core-genome alignment and visualization of thousands of intraspecific microbial genomes. Genome Biol 15:524.

Zankari E, Hasman H, Cosentino S, Vestergaard M, Rasmussen S, Lund O, Aarestrup FM and Larsen MV (2012) Identification of acquired antimicrobial resistance genes. J Antimicrob Chemother 67:2640-2644.

Zhang Y and Gladyshev VN (2005) An algorithm for identification of bacterial selenocysteine insertion sequence elements and selenoprotein genes. Bioinformatics 21:2580-2589.

Zhang Y, Turanov AA, Hatfield DL and Gladyshev VN (2008) In silico identification of genes involved in selenium metabolism: Evidence for a third selenium utilization trait. BMC Genomics 9:251.

Zhang B, Zhou K, Zhang J, Chen Q, Liu G, Shang N, Qin W, Li P and Lin F (2009) Accumulation and species distribution of selenium in Se-enriched bacterial cells of the Bifidobacterium animalis 01 . Food Chem 115:727-734.

Zhong Z, Zhang W, Song Y, Liu W, Xu H, Xi X, Menghe B, Zhang $\mathrm{H}$ and Sun $\mathrm{Z}$ (2017) Comparative genomic analysis of the genus Enterococcus. Microbiol Res 196:95-105.

\section{Supplementary material}

The following online material is available for this article:

Table S1 - General genome features of $E$. durans LAB18S compared with $E$. durans KLDS6.0933.

Figure $\mathrm{S} 1-$ E. durans LAB18S genes grouped into subsystems by RAST.

Figure S2 - Multiple sequence alignment of colicin V gene from $E$. durans LAB18S.

\section{Associate Editor: Guilherme Corrêa de Oliveira}

License information: This is an open-access article distributed under the terms of the Creative Commons Attribution License (type CC-BY), which permits unrestricted use, istribution and reproduction in any medium, provided the original article is properly cited. 